Preliminary communication UDC 177.61(045)

doi: $10.21464 / \mathrm{sp} 33112$

Received: May 11, 2018

\title{
Mpho Tshivhase
}

University of Pretoria, Faculty of Humanities, Lynnwood Road, Hillcrest, ZA-0081 Pretoria

mpho.tshivhase@up.ac.za

\section{Love as the Foundation of Ubuntu}

\begin{abstract}
Ubuntu is widely understood as a moral theory with a scope that is wide enough to explain what counts as the right kind of human behaviour as well as what it means to be a person. Understood in its basic form, Ubuntu is a relational theory about human interaction wherein its main focus could be argued to be a matter of living with raw awareness of the interdependence necessary among people - a kind of interdependence that enables communities to remain united. Herein I want to turn the attention to the meta-ethical analysis of Ubuntu, wherein I explore the possibility of love as a foundation for Ubuntu. What is interesting about Ubuntu in this meta-ethical sense is not the kind of behaviour it inspires in people, but the kind of virtue that sits at its very foundation.
\end{abstract}

Keywords

Ubuntu, love, moral theory, human interaction, virtue ethics

\section{Introduction}

Often when one evaluates an ethical theory, one does so by means of identifying the domains of assessment within which a moral theory operates. ${ }^{1}$ These domains can be action, consequence, character, or motive. Some moral theories, such as virtue ethics and utilitarianism, tend to lean toward one dominant domain to provide the principles that inform moral judgment. Virtue ethics emphasizes character as the domain of moral action, while consequentialism emphasizes the outcome of the action. One also finds moral theories such as deontology, which tend to enable interplay between the domains of action and motive to arrive at moral judgment. Ubuntu presents as an ethic that relies on different domains to evaluate moral behaviour. Seemingly, Ubuntu fits within the domains of character, motive, and consequences. Fainos Mangena (2012) could be said to introduce another domain within which he thinks Ubuntu operates, that is, the dialogical domain. This inter-domain nature of Ubuntu is probably a feature of the theory that makes Ubuntu a unique moral theory - one whose relevance as a normative theory that guides human behaviour happens to be multifaceted, thus capable of explaining different aspects of morally acceptable human behaviour.

The theory of Ubuntu is a widely celebrated African moral theory, which differs from Western moral theories (See Nussbaum, 2003). It is celebrated, in

This paper benefitted from comments given by Lindokuhle Gama, David Barnard, Jurgen Wolfenden, and Nyawasedza Tshivhase.
It was also improved following the feedback from the anonymous reviewers of this journal. 
part, because of its continent of origin. A lot of attention is given to Ubuntu as a theory that is formulated in Africa by Africans, and so, it stands as one of the few, if not the only dominant African moral theory. The existence of Ubuntu as an African moral theory serves an important role in the history of the creation and recognition of different knowledge systems. Thinkers such as Mabogo More (1996), Mogobe Ramose (2002), and Chikudwu Eze (2002), have commented on the view that African people were thought to be incapable of producing any knowledge since that would mean they had the capacity for rationality - a capacity which was (mistakenly) believed to be unique to non-Africans. A lack in rationality came to be seen as a lack in what Aristotle, Immanuel Kant, and others refer to as personhood. While rationality was considered a mark of (descriptive) 'personhood' so that those who lack rationality were considered to be non-persons lacking in the capacity to produce knowledge, thinkers such as Ramose and Felix Murove (2014), paid attention to a different aspect to explain what it means to be a person: Muthu ndi muthu nga vhanwe vhath $u^{2}$ - and - $u$ vha muthu zwi vhonala nga zwiito na kutshilisane kwa muthu na vhanwe. These TshiVenda expressions indicate that Ubuntu is recognisable in the manner in which individuals relate to each other. Put differently, one's personhood is recognisable or becomes evident through one's interconnectedness with others.

This sense of relationality occupies the heart of how we come to recognise Ubuntu, where Ubuntu itself is a relational matter that involves living a life that is comprised of morally praiseworthy behaviour, wherein such praiseworthy behavior is crucial to the harmony and unity of a community. Closely connected to the idea of Ubuntu is the concept of (normative) personhood. Personhood, expressed in relation to Ubuntu, is evident in the way that one relates to other people. Here, personhood becomes valuable as a relational mode of living that necessarily involves morality. The morality expressed in the expressions above conveys Ubuntu.

While relationality and the cultivation of morally praiseworthy behaviour are important human values, I think that it is also important to consider the foundation of the moral theory to which humans are encouraged to aspire. Herein, I aim to advance the argument that Ubuntu should be founded on love - a disinterested love - not in the sense of romantic or friendship love. Herein, the kind of love Ubuntu should be grounded on should be the kind that exists for its own sake and not for the sake of causing something else to happen. In this sense then, Ubuntu cannot be argued to be limited to the people one knows as it is not limited to exist among only those who know each other or can relate to each other due to the close proximity in terms of immediate communal location or corporeal reality. ${ }^{3}$

Ubuntu can be considered a universal moral ethic whose validity is not limited to close relatives, friendships, and romantic relationships. At the very least, Ubuntu is affirmed by the value of care. Caring for others, I will argue, is a matter of recognizing the humanity in another and developing an interest in not disrupting, but rather, enabling and maintaining their wellbeing. Such caring is often a matter of compassion or fellow feeling. The principle of reciprocity, while it drives the relational aspect of Ubuntu, is not the primary goal of Ubuntu. The primary goal of Ubuntu is to ensure the wellbeing of others for the harmony of the society, and I argue that this process of ensuring the wellbeing of others should not be used as the grounding for the definition of Ubuntu. My view is that ensuring the wellbeing of others is a function of Ubuntu, but it does not exhaust the meaning of Ubuntu and the foundation 
thereof. The idea of Ubuntu that is derived mainly from close relations involving friendships, collegiality, family ties, and so forth, limits the meaning of Ubuntu to its instrumentality for human beings and makes humans the foundation of Ubuntu.

In the first section, I will briefly discuss Ubuntu with the aim to explain the basic characteristics of the theory. In the second section, I will discuss the metaphysics of Ubuntu with the aim to argue that the metaphysical analyses of Ubuntu that are provided by Ramose (2002) and Symphorien Ntibagirirwa (2018) do not provide a satisfactory explanation of the foundation of Ubuntu. After that, I will discuss love to sketch out the plausible view that love, and not persons, should be a foundation for Ubuntu. I provide reasons for thinking that the three common forms of love - eros, philia, and agape - do not sufficiently capture the kind of love that should ground Ubuntu. My overarching aim here is to show that without a radically different form of love as grounding for Ubuntu, the meaning of Ubuntu could become limited to make sense primarily in relation to humans. I will argue that it does not make logical sense for persons to be both the foundation and beneficiaries of Ubuntu.

\section{A Brief Overview of Ubuntu}

There are different approaches to Ubuntu. While most of them agree on the basic traits of Ubuntu, they do not always emphasize the same aspects. A thinker such as Augustine Schutte (2001: 7-11) frames Ubuntu in the context of the epistemological productions from Africa in relation to those from the West. Schutte explains Ubuntu as a moral theory that makes sense in relation to Western views. A different perspective appears in Fainos Mangena's treatment of Ubuntu/hunhu wherein he explains Ubuntu in relation to other theories such as utilitarianism, virtue ethics, and deontology with the aim to illustrate that Ubuntu can be interpreted as a multifunctional theory that is constituted by some aspects that are recognizable in utilitarianism, virtue ethics, and deontology. Mangena's aim seems mainly to be a matter of showing that Ubuntu is unique in that it prescribes ethical behaviour based on different domains of ethics namely, action, consequences and duty (Mangena, 2012).

Ubuntu is also viewed as a theory that explains the moral condition of humanness and personhood through the promotion of moral values such as respect, duty, compassion and care; all of which are understood to be values that ensure the wellbeing of others (Prinsloo, 1991; Bennett, 2011).

Felix Murove and Thaddeus Metz argue that the idea of humanness is captured in the relational aspect of Ubuntu, which indicates the deep dependence of the shaping of one's character on communal relationships (Metz, 2007: 323; Murove, 2014: 42, 44). The relationality constitutes a requirement to assist others from a place of goodness, wherein such virtuosity is considered an indication of one's comprehension and acceptance of one's purpose in society, i.e. to contribute positively to the welfare of the community. Such contribution is a necessary condition for the achievement of full personhood,

2

The famous Nguni version of this adage is umuntu ngu muntu nga bantu.

Corporeal existence does not appear to be a sufficient condition for Ubuntu (and personhood) since what it means to be a person, vis-á-vis a morally excellent individual who espouses Ubuntu, extends into the stage of ancestorhood. (Menkiti, 1979). Moreover, Mangena (2012) asserts that the dialogical structure of Ubuntu enables communication between vanhu (humans) and midzimu (ancestral spirits). 
which makes little room for the individuality (Gyekye, 1991: 331; Munyaka \& Mothlabi, 2009: 67). Personhood, with regard to Ubuntu, is best explained in terms of one's disposition toward other persons - a person is a person through his/her relations with other people (Metz, 2007: 323).

Ubuntu is almost always discussed in terms of its value for the community. One could argue that Ubuntu cannot be defined outside of humanity and community. It is meaningful in so far as it benefits humans within a community. This idea that Ubuntu's meaningfulness exists only in relation to the wellbeing of the community is transferred to the goodness of the person so that a person is only considered good in so far as s/he contributes positively to the harmony of the community. This logic is embedded in the characterisation of the relationship between the individual and the community, which is mainly a matter of morality.

I aim to take my cue from Ramose and Ntibagirirwa's discussions of the metaphysical aspects of Ubuntu to argue that both the metaphysical and ethical approaches do not exhaust meta-ethical considerations. Nonetheless, I admit the need for the clarification of the former categories as necessary for the consideration of the meta-ethical structure. I want to consider the view that Ubuntu could derive non-instrumental meaning when understood as grounded in disinterested love, and not the unity of the community. The unity of a community comes about as a result of love. Unity itself does not define Ubuntu.

\section{Metaphysics of Ubuntu}

In this section, I aim to temporarily take the focus away from the moral component of Ubuntu, which has been the dominant focus in debates on Ubuntu theory. While it is fundamental to consider Ubuntu for its moral impetus, I think it is equally important to consider what constitutes the foundation of Ubuntu. Herein, I want to argue that what grounds Ubuntu is not its social value or the way that Ubuntu influences individuals to become good persons. I am wondering whether it is possible to think of Ubuntu as grounded in something other than what it does for society or, put differently, how it benefits humanity? Most thinkers, such as Barbara Nussbaum (2003) and Desmond Tutu (1999), who write on Ubuntu successfully, express the nature of Ubuntu in altruistic terms. They also illustrate its value for society in the way that Ubuntu ensures the unity and harmony of a community. Other thinkers, like Metz (2007), Murove (2014), and Ramose (2002), focus on defending the validity of Ubuntu as an ethical theory worthy of serious consideration in Philosophy in general. None of these approaches to Ubuntu satisfy my curiosity regarding Ubuntu as a moral theory that is meaningful regardless of whether humans take it seriously for a scholarship or find it beneficial for their status as social beings whose existence necessitates relationality of some form or another.

One finds at least two thinkers who discuss Ubuntu in terms of the interplay between the moral and the metaphysical aspects of Ubuntu. Ramose and Ntibagirirwa share an appreciation of the moral sense of Ubuntu being intelligible when regarded as grounded on the metaphysical component of it. While their aims are different, they both use the metaphysical as grounding for the moral nature of Ubuntu. Both considerations are useful in the understanding of Ubuntu - that much one cannot deny. However, none of them considers Ubuntu in isolation from human beings, as such, so that both views ultimately find Ubuntu valuable in so far as it is useful to human beings vis-á-vis community.

There are some aspects of Ramose (2002) and Ntibagirirwa (2018) that are useful for the argument I want to make in relation to the foundation of Ubun- 
tu. Ultimately, I reject both Ramose and Ntibagirirwa's assertions regarding the interplay between the metaphysical and the moral impetus of Ubuntu. My overarching reason for rejecting both approaches is that they derive an 'ought' from a 'is' so that 'Ubuntu' and 'umuntu' become inseparably identical. For Ramose umuntu is Ubuntu incarnate, for Ntibagirirwa, Ubuntu is humanness so that being a human being is recognized through illustrating humanness which remains loyal to the view that being human is tantamount to having Ubuntu. In my view, what we have here are views on Ubuntu that explain what people should become in descriptive terms of what they are, hence the deviation from what they are is then regarded as inhumane - unnatural, if you will.

My observation may make clearer sense when one considers that Ubuntu in terms of personhood. Herein a person is recognized in his/her relations to others so that any form of existence outside the relation to others is considered closer to animals than persons. In this way, personhood takes a communitarian stance that prioritizes the community over the individual (see Tshivhase, 2018). Simultaneously, personhood is defined in moral terms so that what it means to be a person is to be morally good. Thinkers such as Menkiti (2004), Masolo (2010), and Wiredu and Gyekye (1992) argue about the primacy of the community in the relationship between persons and community, but they hardly disagree about personhood being a matter of moral goodness. The main point of divergence has to do with the idea of personhood being acquired, where Gyekye and Wiredu, contra Menkiti, argue that being a person is not something an individual acquires. Rather, what one "acquires are status, habits, and personality or character traits" (Wiredu \& Gyekye, 1992: 108). My point is that, given Ubuntu determining who persons ought to become, the theory determines whom a person ought to be in terms of what they are. Put differently, the nature of persons is presented as a matter of moral goodness so that what one is becomes a matter of whom one should become, i.e. a morally praiseworthy being.

The ontological and epistemological structures of Ubuntu, as determined by Ramose, do not escape this problem. Ramose (2002) considers Ubuntu in terms of what he considers the ontological and epistemological elements, while Ntibagirirwa (2018) considers Ubuntu through what she considers a metaphysical lens. I discuss these two views separately as Ntibagirirwa intentionally contradicts Ramose's approach and finds it wanting as it does not cover the fact of Ubuntu as a theory whose universality resides in the 'ntu'.

Ramose offers an analysis of Ubuntu that illustrates Ubuntu in terms of its ontological and epistemological structure. He conceives of Ubuntu as a fifth category within the categories of existence in the Bantu philosophy. The four categories, which he states he adopts from Alexis Kagame, are kintu, hantu, bantu, and kuntu. Ubuntu becomes the fifth category, which Ramose argues, should permeate the other four categories. According to Ramose, Ubuntu is constituted by the prefix $u b u-{ }^{4}$ and the suffix $-n t u$ where 'ubu' expresses the highest form of universality which captures the 'ness' of all that exists. Herein, Ramose uses 'ubu-' to capture the nature of existence (of anything) as a process of becoming. In this sense, be-ing is a kind of progression that never

4

Ntibagirirwa explains it differently. She characterizes the prefix as 'bu' as opposed to 'ubu', as Ramose states it. My view is that this is a mistake as it misrepresents Ramose's assertion, especially within the context of South African language, IsiZulu in particular.
' $u$ ' in the IsiZulu language is never separated from the object. In short, separating the 'bu' from ' $u$ ' betrays the structure of the language and fails to represent Ramose's assertions accurately. 
reaches concrete finality. Ramose worries that concreteness, which he argues is contained in the form of an 'ism', creates fragmentation which is further enabled by the unchanging dogmas that are grounded in static existence. In his view, such concreteness precludes a genuine search for knowledge (Ramose, 2002: 324-326).

'Ntu', as the second part of Ubuntu, is then understood as the tangible form which 'ubu' moves through. The 'ntu' can be present in the world as a thing, a place and time, a modality or a human being. '-ntu' is the epistemological aspect of Ubuntu, while 'ubu-' is the ontological aspect (Ramose, 2002: 324-325). In this respect, it is important for Ramose to make this distinction between the ontological and the epistemological, but only on a conceptual level. In the every day, ubu-ntu becomes meaningful only when it is discussed in terms of the umuntu (ibid). Herein the centrality of the human being is brought to the fore so that the meaningfulness of Ubuntu in its epistemological and ontological senses only attracts meaning when we take the human being as its locus.

Interestingly, Ntibagirirwa interrogates the idea of the human as the locus of Ubuntu and asks, "where Ubuntu of the muntu resides?" (2018: 125). Her answer to this question involves creating a dichotomous perception of the location of Ubuntu. Ubuntu then, is located in the heart and intelligence. Ntibagirirwa argues that intelligence is the faculty that distinguishes human beings from other beings. It is through intelligence that humans interact with, evaluate, appreciate, and relate harmoniously with other beings (2018: 125-126).

Ntibagirirwa also relies on the four categories that structure Bantu Philosophy, namely kintu, muntu, hantu, kuntu (2018: 116-117). Contra Ramose, Ntibagirirwa argues that '-ntu' is the general/universal force, instead of the 'ubu-'. Furthermore, being should be understood a posteriori so that what it means to exist necessarily involve interaction with other beings in the world. Nonetheless, she agrees with Ramose that Ubuntu is the fifth category of African Philosophy and that the human is the foundation that renders Ubuntu meaningful.

My view is that placing human beings as the center of Ubuntu, renders the concept of Ubuntu meaningless outside the existence of the umuntu. While it is true that humans are beings whose existence is necessarily social, I do think it is a mistake to think of the meaning of Ubuntu as derived solely from the existence of human beings. Rightly so, humans are, from time to time, confronted by situations that require them to exercise moral deliberation where Ubuntu could offer the guiding principles for appropriate moral behaviour. Herein Ramose and Ntibagirirwa make compelling arguments regarding the relationality of the human condition (Ntibagirirwa, 2018: 129; Ramose, 2002: 326). I do not deny the that 1) Ubuntu is both ontological and epistemological; 2) Ubuntu is an ethical theory whose principles are oriented toward harmony; 3) that Ubuntu is a relational concept; and 4) that the metaphysical analysis of Ubuntu provides grounding for the moral aspect of Ubuntu. My view is that we should be concerned, not with just locating where Ubuntu resides in the human being, but also with the grounding for Ubuntu, where such grounding need not be instrumental to humans. In other words, I am enquiring whether there is a foundation that gives meaning to Ubuntu outside of its instrumental purpose for human beings. One plausible view of the foundation of Ubuntu is love. I want to sketch a view of Ubuntu that is grounded in love, where such love is not limited to human beings, but applies to all living things - a love for life, as it were. 


\section{Love as a foundation of Ubuntu}

Love, in a sense I am thinking of it here as the plausible grounding for Ubun$\mathrm{tu}$, is neither erotic nor does it resemble friendship. I do not use any of these conceptions of love, not because they are inappropriate but because they do not fit the kind of neutrality that I think should ground in Ubuntu. I think that the kind of love that should ground Ubuntu should be the kind of love renders Ubuntu valuable for its own sake. For Ubuntu to derive meaning independently of its instrumentality for humans, it ought to be grounded in something that gives it meaning intrinsically, and not for the sake of bringing about something else.

Although love always has an object, the meaning of love should not be determined by that object and it should not be determined by the wellbeing of that object. The object of love and its wellbeing are associated with love. They do not define love, but they can derive sentimental value in the experience or moment of being loved. An unattached theory of love may provide such grounding for Ubuntu, as it would avoid the centralisation of the (human) beloved. I will use this section to discuss the view of love I find useful for the meaning of Ubuntu that does not depend solely on how it benefits humans. I will explain the different senses of love to arrive at the sense that I think is relevant for a definition of Ubuntu that is not primarily and/or solely driven by its instrumental value for humans.

Love, in general, is considered a concept that is characterised by different features that have to do with relation to another (Reis \& Aron, 2008: 80, 82). Love can also be viewed as an emotion that offers a reason for acting. Put differently; it is a state of feeling that occurs in relation to an object or a state of affairs (Zemach, 2001: 197-198). Furthermore, love has an intentional structure that can be self-interested or altruistic (Zemach, 2001: 197; Solomon, 2007: 52, 54). Often, one's object of affection provides good reasons for loving. There exists different forms of love namely, 1) eros - love that is characterized by sexual desire; 2) agape, which is defined in terms of altruism that, when viewed through the Christian theology, came to be seen as a divine kind of love that only God could have - this is love for humanity; and 3) Philia, which is the kind of love that exists in friendships love (Solomon 2007: 52-54; La Caze, 2005: 102-103).

Love is largely considered to be a beautiful thing and so it is often received positively. However, love, especially romantic love can be irrational and obsessive. Robert Solomon argues that love is a matter of subjectivity and can be considered irrational, mainly because it is quite subjective. He states that subjectivity in love ought to be respected, but this does not mean that people should ignore some forms of irrationality that can be inappropriate, i.e. incest (2007: 56). Love also presents a kind of emotional vulnerability that can be limited to how $A$ treats $B$, but it can also involve how what happens to $A$ can affect $B$ (Kolodny, 2003: 152). The idea of love as kind of valuing that makes one vulnerable, as construed by Kolodny, is echoed in David Velleman's view that love is a response to the incomparable value of an individual wherein such valuing leaves us vulnerable to the incomparably valuable individual (1999: 366).

Friendship and erotic forms of love have the potential of creating silos that necessarily exclude others to maintain harmony. Ramose calls this bounded reasoning (2002: 329). The idea of bounded reasoning involves caring for those whom one considers close and important. Such valuation of others necessary excludes those who exist outside the circle of care (ibid.). One finds 
this idea of partiality in forms of love that turn the object of love into a focus of their attention and actions. Such a focus can easily bring about gatekeeping in favour of the beloved and other problems such as favouritism, in the form of nepotism and other acts that advantage the lover, often at the cost of others (see also: Ramose, 2002).

The forms of love I have discussed above all involve a reason for love that illustrates that love exists to maintain some sort of relationship between persons. These forms of love can easily turn sour as they open up a possibility of possessiveness in some form or other. Love for another human, whether in the sense of erotic, friendship or a general love for humanity, seems to involve an appropriation of value that can involve assimilation. Ubuntu, in the moral sense that involves a level of care that ensures the welfare of others, could be interpreted to have assimilation as a necessary condition for communal life. Herein, Ubuntu seems to express harmony, moral goodness and solidarity as aspects of human life that are valuable in so far as they can be appropriated for some social benefit. What I think would be a better alternative for what should be considered to be the grounding for Ubuntu is a kind of love that has no isolated predetermined focus. This could give the impression that moral goodness is a kind of hostage to social welfare and communal unity, wherein goodness is not valuable in itself but rather for the benefit of other people.

The advantage of viewing Ubuntu as grounded on love is that it becomes valuable in and of itself. Ubuntu can be viewed independently of how others aspire to or diverge from it. I have in mind an image of Ubuntu as a concept that exists not primarily for anything outside itself and whose meaning holds, even when no one aspires to or champions it or even when no community benefits from it. Imagine the shade of a tree - it is there every day even if no-one or no-thing finds refuge in the shade, uses the shade or recognises that it is there, to begin with. I think positioning love as a foundation of Ubuntu, allows for such conceptualisation. While Ubuntu does involve a form of love for humanity, this conception of love does not fit my idea of what ought to be the foundation of love as it is readily directed toward a particular object, humanity. For Ubuntu to properly open up as, in part, the highest form of generality, it should not be strictly or primarily defined in terms of humanity.

Moreover, I think there is a need to rethink the relationship between Ubuntu and humanity. Humanity, in my view, does not give rise to Ubuntu as such. Also, I do not think it is humanity that gives Ubuntu meaning. To think Ubuntu derives meaning from humanity (or how it benefits humanity) is to deny Ubuntu a definition that contains meaning independently of how humans perceive it so that the nature of Ubuntu is necessarily becoming human-centered. It is plausible to think of humanity, not as the locus of Ubuntu as Ntibagirirwa would have it, but rather as the action-guiding theory for humanity with a foundation that can exist outside of humanity. Herein, I accept that it is often in the encounter with the other that Ubuntu is invoked. For instance, a phone does not move one to respond morally toward it as an object. However, the other need not, in every case, be human. The 'other' could be any living being that one encounters, and whose presence necessarily invokes Ubuntu as an appropriate response to that 'other.'

Ubuntu places emphasis on caring and sharing as values that stand ours in the inextricable connectedness of people within a community. These values speak directly to famous Ubuntu aphorism - umuntu ngumuntu nga bantu - which captures the deeply rooted relationality of persons in a community (Metz, 2011: 536-537, 540); Etieyibo, 2017: 318-319). Here is it natural to 
think that virtues of sharing, caring, and friendship develop and are practised within the context of community. It is not incoherent to think of community as a context of Ubuntu and by extension, the context of love. Nonetheless, to think of love as a contextual aspect of humanity could aid in maintaining the idea of humans as the centre of these virtues, and so, make humans the beings who provide meaning for a virtue such as love.

I contend that such a view of closes love off to derive meaning only from humanity so that other living beings only come to matter or experience love when humans interact with or recognize them. Considered in this way then, non-humans would experience Ubuntu only when they encounter humans. What I am contesting here is the centrality of humans in Ubuntu. The definition of Ubuntu, while one experiences in the context of others, should not be grounded on an idea of 'others' that focuses only on humans. There are, at least, two general reasons that should help caution against a human-centered foundation of Ubuntu. The first one has to do with the possibility of elevating the status and value humans based on the idea that they have special ways of relating to others; an ability that animals lack (Metz, 2011: 544). These could include virtues such as care, compassion, friendship, and so forth. The second cause for concern has to do with the misinterpretation of love where punishment can be considered a form of love that is aligned with the virtues of Ubuntu. The idea of punishment as love opens avenues that enable the defence of abusive behavior as illustrations of Ubuntu in the sense of said punishment being good for the unity of the community (Chisale, 2016). The context of love in this sense forces one to question the actions that are endorsed in different contexts in the name of Ubuntu. Gender inequality is one illustration of an aspect about the community that depends, in most cases, on culture. Cultural relativity complicates the story of Ubuntu as displays of commitment to Ubuntu are not always virtuous. Although context matters for both love and Ubuntu, it is unclear that every human-centered context is genuinely committed to the principles of Ubuntu in a morally acceptable way that would also apply to all living beings.

In sum, the form of love I support to be the foundation for Ubuntu is not based on a single focus. Herein there is no beloved; there is simply love - a kind of love whose object is everything and nothing at the same time. The nature of this love is such because nothing in the universe stays the same and so the fluidity of existence requires a mode of love that is not fixated on the concrete aspect of anything since everything is at any one point something which becomes nothing at some moment or other. A love that is fixated on something is limiting and limited. For instance, one possible limit is evidence in the death of a pet - when love is directed to the pet that dies, the grief can be so devastating that one refuses to love another pet, and so, does not get another pet so as to preserve the authenticity of the love of the pet that dies - as if getting another pet nullifies the existence of the pet that died. The point is that this kind of possessive or attached love can be paralysing and it can prevent one from spreading the love, as it were. Love of something or someone or some species is too concentrated and too attached to serve as a foundation for Ubuntu.

Ubuntu, when founded on love, would not require reciprocity - the golden rule would not be an aspect of it. Also, it would not derive from how humans ought to behave to bring something about, i.e. welfare of the community. If we want to view Ubuntu as the highest form of generality, then we cannot have it focused on maintaining a particular kind of social relationship. 


\section{Conclusion}

Ubuntu is a relational concept that prioritises the welfare of the community for the sake of harmony and encourages good behaviour to maintain morality in society and guide the process of the development of personhood. If Ubuntu is to truly permeate through all the four categories of African philosophy, without presenting humans as hierarchically above the other categories, then we may want to consider the view that Ubuntu is not grounded in how to perceive and appropriate it. When we maintain a view of Ubuntu that is human centered, we risk prescribing behavior to them that is already part of their nature. The view of Ubuntu as personhood is somewhat, an illustration of such a mistake.

Most views on Ubuntu imply that Ubuntu only assumes meaning at the moment it is discussed in relation to humans. I find this troubling as it makes humans, at the same time, the foundation of Ubuntu as well the agents who are themselves defined by Ubuntu. Furthermore, the relation between persons and Ubuntu is one that can be captured as deriving an ought from an is. Ubuntu prescribes how persons ought to behave based on what they are, i.e. muntu's whose humanness is already considered to be good. This concern moves me to think that Ubuntu cannot have humans as its foundation. I suggested that a kind of love that is not attached or pre-directed toward some object should be the foundation for Ubuntu so that Ubuntu can become a universal term whose meaning is not dependent on how human assimilate or appropriate it. This view does not exhaust the possible alternative that could express the foundation, but opens up a different approach to Ubuntu, one that does not change the meaning of Ubuntu as such, but enquires about the foundation of Ubuntu, where love that has no particular object could qualify as a foundation of Ubuntu.

\section{References}

Chisale, S. S. 2016. "Love, Discipline, Punishment or wife battering: A View From Ubuntu”. Gender and behavior 14 (2016) 2. PP. 7275-7283.

Eze, E. C. 2002. "The Colour of Reason: The Idea of 'Race' in Kant's Anthropology". In: Coetzee, P. H.; Roux, A. P. J. (eds. 2003). Philosophy from Africa: A Text with Readings. Cape Town: Oxford University Press. PP. 430-456.

Kolodny, N. 2003. "Love as Valuing a Relationship". The Philosophical Review 112 (2003) 2. PP. 135-189.

Mangena, F. 2012. "Towards a Hunhu/Ubuntu Dialogical Moral Theory". Phronimon: Journal of the South African Society for Greek Philosophy and the Humanities 13 (2012) 2. PP. 1-17.

Masolo, D. A. 2010. Self and Community in a Changing World. Indiana (USA): Indiana University Press.

La Caze, M. 2005. "Love, That Indispensable Supplement: Irigaray and Kant on Love and Respect”. Hypatia 20 (2005) 3. PP. 92-114. doi: https://doi.org/10.1353/hyp.2005.0100.

Menkiti, I. A. 2004. "On the Normative Conception of a Person”. In: Wiredu, K. (ed). A Companion to African Philosophy. Oxford: Blackwell Publishing. PP. 324-331.

Menkiti, I. 1979. "Person and Community in African Traditional Thought". In: Wright, R. (ed.). African Philosophy. Washington, D.C: University Press of America. PP. 157-168.

Metz, T. 2007. "Toward an African Moral Theory”. Journal of Political Philosophy 15. PP. 321-341.

More, P. M. 1996. “African Philosophy Revisited”. Alternation 3 (1996) 1. PP. 109-129. 
Munyaka, M.; Mothlabi, M. 2009. "Ubuntu and its Socio-moral Significance”. In: Murove, F. M. (ed.). African Ethics: An Anthology of Comparative and Applied Ethics. Pietermaritzburg: University of KwaZulu Natal. PP. 62-84.

Murove, M. F. 2014. “Ubuntu”. Diogenes 59 (2014) 3-4. PP. 36-47. doi: https://doi.org/1 $0.1177 / 0392192113493737$.

Ntibagirirwa, S. 2018. "Ubuntu as a Metaphysical Concept". Journal of Value Inquiry 52 (2018) 1. PP. 113-133. doi: https://doi.org/10.1007/s10790-017-9605-x.

Nussbaum, B. 2003. "African Cultures and Ubuntu: Reflections of a South African in America". Perspectives 17 (2003) 1. PP. 1-12.

Prinsloo, E. D. 1991. “African Conceptions of Personhood and Intellectual Identities”. In: Coetzee, P. H.; Roux, A. P. J. (eds. 2003). Philosophy from Africa: A Text with Readings. Cape Town: Oxford University Press. PP. 41-51.

Ramose, M. B. 2002. "The Ethics of Ubuntu". In: Coetzee, P. H.; Roux, A. P. J. (eds. 2003). Philosophy from Africa: A Text with Readings. Cape Town: Oxford University Press. PP. 324-330.

Reis, H. T.; Aron, A. 2008. "Love: What Is It, Why Does It Matter, and How Does It Operate?". Perspectives on Psychological Science 3 (2008) 1. PP. 80-86. doi: https://doi. org/10.1111/j.1745-6916.2008.00065.x.

Schutte, A. 2001. Ubuntu: An Ethic for a New South Africa. Cape Town: Cluster Publications.

Solomon, R. C. 2007. True To Our Emotions: What Our Emotions Are Telling Us. New York: Oxford University Press.

Tshivhase, M. 2018. "The primacy of the personal". In: Ogude, J. (ed.). Ubuntu and Personhood. London: Africa World Press.

Tutu, D., 1999. No Future Without Forgiveness. New York: Random House.

Velleman, J. D. 1999. “Love as a Moral Emotion”. Ethics 109 (1999) 2. PP. 338-374. doi: https://doi.org/10.1086/233898.

Wiredu, K.; Gyekye, K. 1992. Person and Community: Ghanaian Philosophical Studies. Washington DC: Council for Research in Values and Philosophy.

Zemach, E. M. 2001. "What is Emotion?”. American Philosophical Quarterly 38 (2001) 2. PP. 197-207.

\section{Mpho Tshivhase}

\section{Ljubav kao osnova Ubuntua}

\section{Sažetak}

Ubuntu je široko razumljen kao teorija morala sa širinom dovoljnom da objasni što se smatra ispravnim ljudskim ponašanjem, kao i to što znači biti osoba. Razumljen u osnovnom obliku, Ubuntu je relacijska teorija o ljudskoj interakciji, a moglo bi se reći da je glavni fokus na način življenja s golom svijesti o potrebitoj međuovisnosti među ljudima - vrsti međuovisnosti koja omogućuje da zajednica ostaje cjelovita. Ovdje se želim osvrnuti na meta-etičku analizu Ubuntu filozofije, pri čemu ispitujem mogućnost ljubavi kao njene osnove. Ono što je zanimljivost Ubuntu filozofije u ovom meta-etičkom smislu nije to kakvo ponašanje pobuđuje u ljudima, nego kakva se vrlina nalazi u njezinoj osnovi.

\section{Ključne riječi}

Ubuntu, ljubav, teorija morala, ljudska interakcija, etika vrlina 


\section{Mpho Tshivhase}

\section{Liebe als Grundlage des Ubuntu}

\section{Zusammenfassung}

Ubuntu wird weithin als Moraltheorie verstanden, deren Breite ausreicht, um zu erklären, was als korrektes menschliches Verhalten angesehen wird und was es zudem bedeutet, eine Person zu sein. In der Grundform begriffen ist Ubuntu die relationale Theorie der menschlichen Interaktion, und es kann gesagt werden, dass der Schwerpunkt auf der Lebensweise liegt, wobei man nacktes Bewusstsein für die unumgängliche Interdependenz zwischen den Menschen entwickelt - eine Art Interdependenz, die es der Gemeinschaft erlaubt, ganzheitlich zu bleiben. Ich möchte hier die metaethische Analyse der Ubuntu-Philosophie in Erwägung ziehen, wobei ich die Möglichkeit der Liebe als ihrer Grundlage prüfe. Was aber interessant an der Ubuntu-Philosophie in diesem metaethischen Sinne ist, ist nicht die Art des Verhaltens, das sie in den Menschen auslöst, sondern was für eine Tugend in ihrem Kern liegt.

\section{Schlüsselwörter}

Ubuntu, Liebe, Moraltheorie, menschliche Interaktion, Ethik der Tugenden

\section{Mpho Tshivhase}

\section{L'amour comme fondement de l'Ubuntu}

\section{Résumé}

L'Ubuntu est principalement comprise comme une théorie morale suffisamment large pour expliquer ce qu'est un comportement humain juste, mais également ce que signifie être une personne. D'un point de vue de sa forme principale, l'Ubuntu est une théorie relationnelle sur l'interaction humaine, mais il est possible d'affirmer qu'elle se focalise principalement sur la manière de vivre à l'état de pure conscience et sur le besoin d'interdépendance parmi les gens - genre d'interdépendance qui permet à la communauté de rester entière. Je souhaite ici me pencher sur l'analyse méta-éthique de la philosophie Ubuntu en interrogeant ainsi la possibilité que l'amour en constitue le fondement. Ce qui est intéressant dans la philosophie Ubuntu dans le sens méta-éthique ne concerne pas le comportement qu'elle réveille chez les gens, mais quelle vertu se trouve dans son principe.

\section{Mots-clés}

Ubuntu, amour, théorie de la moralité, interaction humaine, éthique des vertus 